\title{
In Vitro Antioxidant Capacity of Crude Extracts and Acetogenin Fraction of Soursop Fruit Pulp
}

\author{
León-Fernández $A E^{1}$, Sáyago-Ayerdi SG ${ }^{1}$, Velázquez-Estrada RM ${ }^{1}$, Zepeda-Vallejo LG $^{2}$, Yahia $E^{3}$, Montalvo-González $E^{1^{*}}$ \\ ${ }^{1}$ Laboratorio Integral de Investigación en Alimentos. Instituto Tecnológico de Tepic, México \\ ${ }^{2}$ Escuela Nacional de Ciencias Biológicas-IPN, México \\ ${ }^{3}$ Facultad de Ciencias Naturales, Universidad Autónoma de Querétaro, México
}

*Corresponding author: Montalvo-González E, Instituto Tecnológico de Tepic, Av. Tecnologico 2595, Lagos del Country, Tepic, Nayarit, México, CP 63175, Tel: 52 (311) 211-94 00 ext. 328; E-mail: efimontalvo@gmail.com

Received date: May 17, 2016; Accepted date: May 19, 2017; Published date: June 19, 2017

Copyright: @2017 León-Fernández E, et al. This is an open-access article distributed under the terms of the Creative Commons Attribution License, which permits unrestricted use, distribution, and reproduction in any medium, provided the original author and source are credited.

Abstract
Extracts using chloroform, methanol-acetone, aqueous, and an acetogenin fraction obtained from soursop fruit
pulp were analyzed by measuring total soluble phenolic compounds and antioxidant activities using the assays:
scavenging 1,1-diphenyl-2-picrylhydrazil (DPPH) radical, 2,20 -Azinobis-3-ethylbenzotiazoline-6-sulfonic acid (ABTS)
radical, reducing power, nitric oxide radical, and total antioxidant capacity. Methanol-acetone extract had higher total
soluble phenolic compounds ( $3.24-3.95 \mathrm{~g} / 100 \mathrm{~g}$ DW), antioxidant capacity by DPPH ( $47.9 \mathrm{mmol}$ TE/g DW) and total
antioxidant capacity ( $221.96 \mu \mathrm{g}$ - $\mathrm{a}$-tocopherol equivalent). However, analysis by $\mathrm{ABTS}$, reducing power and nitric
oxide radical methods also showed high antioxidant capacity in aqueous extract. Chloroform extract and acetogenin
fraction had higher antioxidant capacity when using the reducing power method (23.85 and $21.77 \mu \mathrm{M}$ AA equivalent,
respectively), and was higher than in aqueous extract. Our results suggest that soursop pulp is a good source of
antioxidants and has acetogenins, making the fruit a potentially important functional food.

Keywords: Annona muricata; Acetogenin; Antioxidants; Functional food; Health; Total polyphenols

\section{Introduction}

Annona muricata is a popular fruit from Central America, Antilles and North and South America, known as "soursop", "guanábana" or "graviola", and cultivated in several countries including Mexico, Brazil, Venezuela and Costa Rica [1]. Soursop pulp is a good source of dietary fiber [2] and was found to contain a variety of interesting phytochemicals with potential health benefits [3].

There is an increasing interest for bioactive compounds due to their nutraceutical properties. For example, polyphenols are natural compounds in all plants, many with antioxidant activity that can protect against cellular damage caused by free radicals [3]. It has been found that phenolic compounds are associated with a wide range of health processes related to diverse diseases such as cancer, diabetes, cardiovascular and anti-inflammatory diseases [4].

Acetogenins (ACGs), bioactive compounds, have a long aliphatic chain of 35 to 37 carbons bound at one, two or three adjacent tetrahydrofuranic rings, with $\alpha, \beta$ unsaturated lactonic ring [5]. Some studies have reported the presence of ACGs in different parts of Annonaceae plants, and their anticancerous effect have been shown in several cancerous cell lines as prostate, liver, and lung [6,7], and antitumoral activity in murine models [8,9]. ACGs inhibit the mitochondrial complex I: NADH ubiquinone oxidoreductase, which decreases ATP production causing apoptosis [5]. However, there is almost a lack of information on their antioxidant capacity [10].

Different assays are used to measure antioxidant capacity in foods and biological samples. Currently, the most commonly used methods for measuring antioxidant capacity are: 2,20 -azino-bis-3- ethylbenzthiazoline-6-sulphonic acid (ABTS), 1,1-diphenyl-2picrylhydrazyl (DPPH) assay and ferric reducing ability assay, a lesser extent scavenging of nitric oxide (NO) radical assay. Although these methods (except the NO assay) are non-physiological radicals, they describe the ability of redox molecules in foods and biological systems to scavenge free radicals. The single electron transfer (SET) antioxidant assays determine the synergistic and antagonistic effects of combining binary mixtures of antioxidants [11].

Soursop fruit pulp contains significant phenolic content (0.0104-1.86 g EAG/100 g DW) [2,12] and ACGs [13], but very little is known on the antioxidant activity of different extracts with solvents or acetogenin. In addition, the antioxidant capacity by scavenging of nitric oxide (NO) radical assay has yet to be elucidated. In this study, the in vitro antioxidant activities of three different extracts, as well as acetogenin fraction of Annona muricata fruit pulp were evaluated.

\section{Materials and Methods}

\section{Plant material}

Soursop fruit (Annona muricata L.) were harvested at physiological maturity (light green skin and separated tan-colored spines) and with uniform sizes, from orchards located in the community of "El Tonino" Compostela, Nayarit, Mexico. Fruit were ripened at $25^{\circ} \mathrm{C}$ and $80-90 \%$ relative humidity until they reached total soluble solids content of $15-19^{\circ}$ Brix. Fruit samples were then frozen at $-70^{\circ} \mathrm{C}$ and freeze-dried at $-50^{\circ} \mathrm{C}$ and $0.12 \mathrm{~m}$ bar using a LABCONCO (Model 77522020, Kansas, EU.) freeze dryer. 


\section{Obtaining of methanol-acetone and aqueous extracts}

Methanol-acetone extract was obtained from $0.5 \mathrm{~g}$ freeze-dried pulp with $20 \mathrm{ml}$ of a mixture $(50: 50 \mathrm{v} / \mathrm{v})$ of acidified methanol $(0.8 \%$ of $\mathrm{HCl}$ $2 \mathrm{~N})$ and acetone-water solution $(80: 20 \mathrm{v} / \mathrm{v})$, stirred for $1 \mathrm{~h}$, then centrifuged for $30 \mathrm{~min}$ at $9380 \mathrm{~g}$ at $4^{\circ} \mathrm{C}$, and supernatant was graduated to $50 \mathrm{ml}$ [14]. Aqueous extraction was obtained with $0.5 \mathrm{~g}$ of freeze-dried pulp and $20 \mathrm{ml}$ of water, stirred for $1 \mathrm{~h}$, and centrifuged under the same conditions mentioned above. The supernatant obtained was used for analysis.

\section{Acetogenin fraction}

A mixture of $100 \mathrm{~g}$ of soursop freeze-dried pulp in $250 \mathrm{~mL}$ with chloroform was used, and treated for $3 \mathrm{~h}$ at a constant frequency of 42 $\mathrm{kHz}$ in an ultrasonic equipment (Cole-Parmer 8891, Illinois EU.). The extract was filtered and supernatant was evaporated to dryness. Ten mg of dryer extract was used for analysis (chloroform extract) and the rest was chromatographed in an open column $(6.4 \times 57.0 \mathrm{~cm}, 80 \mathrm{~g}$ of $\mathrm{SiO}_{2} 60$ mesh) with $\mathrm{CHCl}_{3} / \mathrm{CH}_{3} \mathrm{OH}$ (chloroform/methanol) as eluents (starting with $100 \%$ chloroform to $100 \%$ methanol) to produce 35 fractions of $200 \mathrm{ml}$. Two $\mu \mathrm{l}$ of each fraction were applied to thin layer chromatography (TLC) $(5 \times 5 \mathrm{~cm}$ silica plates Analytical Chromatography, HX312859, Germany) in order to determine the presence of acetogenins [13]. The development was performed with Kedde reagent [15], and anonnacin standard (Biobhiopha-BBP02455) was used as a positive control. Initial chloroform extract and fraction 10 (Figure 1) which was positive with Kedde reagent in presence of acetogenins were used for analysis of the antioxidant activity. The acetogenin fraction $(10 \mathrm{mg}$ ) and chloroform extract were suspended with $1 \mathrm{ml}$ of chloroform for analysis.

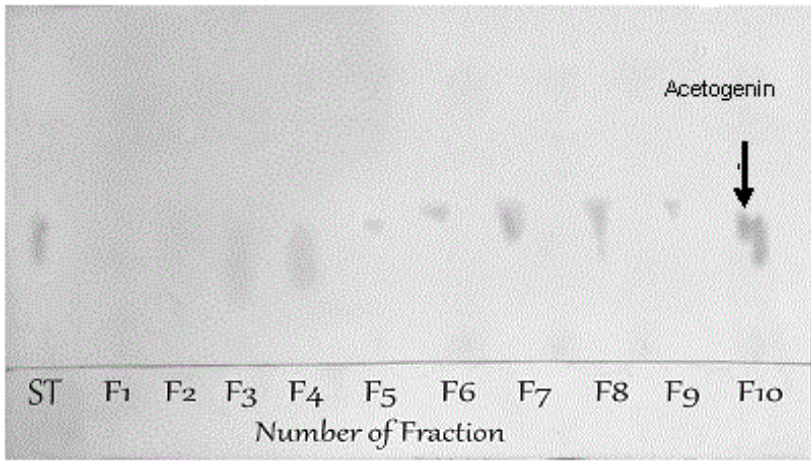

Figure 1: Thin layer chromatography of 10 fractions obtained from chloroformic crude extract by separation with open column. ST= annonacin standard.

\section{Total soluble phenolic compounds (TSP)}

TSP content in methanol-acetone and aqueous extracts $(5,10,20$, 30,40 and $50 \mu \mathrm{l}$ ) was quantified using the Folin-Ciocalteu reagent [16] with slight modifications [17]. Fifty $\mu \mathrm{L}$ of chloroform extracts and acetogenin fraction were used. The absorbance was measured at 750 $\mathrm{nm}$, using a microplate reader (Bio-Tek', Synergy HT, USA) in a multimode spectrophotometric detection with 96-well plates, and Gen5 Program was used. TSP were calculated using a calibration curve of gallic acid, and the results were expressed as g gallic acid equivalents per $100 \mathrm{~g}$ of sample on a dry weight basis (g GAE/100 g DW).

\section{1,1'-Diphenyl-2-picrylhydrazyl (DPPH) radical scavenging assay}

The three extracts, acetogenin fraction and control antioxidant (ascorbic acid standard, $100 \mathrm{mM}$ ) were used to evaluate the antioxidant activity using the reduction of the DPPH radical assay. DPPH assay was carried out according to Prior et al. [18] with some modifications [17]. DPPH (5 mM) was dissolved in pure methanol to a concentration of $190 \mu \mathrm{M}$, and was kept in the dark. The quantities of 5, $10,20,30,40$ or $50 \mu \mathrm{l}$ of the extracts were added to $200 \mu \mathrm{l} \mathrm{DPPH}$ solution and incubated at room temperature in the dark for $30 \mathrm{~min}$. Fifty $\mu \mathrm{L}$ of chloroform extracts and acetogenin fraction were used for this assay, and absorbance was measured at $517 \mathrm{~nm}$ using a microplate reader (Biotek, Synergy HT, Winooski, VT, USA). Trolox (6-hydroxy2,5,7,8-tetramethylchromane-2-carboxylic acid) was used as the standard to report antioxidant activity as millimole of Trolox Equivalent per g of sample DW (mmol TE/g DW).

\section{2,20-Azinobis-3-ethylbenzotiazoline-6-sulfonic acid (ABTS) radical scavenging assay}

The mentioned extracts and antioxidant control were used to evaluate the antioxidant activity using the ABTS radical assay based on the method of Re et al. [19] with some modifications. ABTS (7 mM) was dissolved in potassium persulphate $(2.42 \mathrm{mM})$ and kept in the dark at room temperature for $14 \mathrm{~h}$. The solution was adjusted with phosphate buffer at an absorbance of $0.70( \pm 0.02)$. The same quantities of extracts listed above, antioxidant control, chloroform extract and acetogenin fraction, were added to $280 \mu \mathrm{l}$ ABTS solution, and incubated at $37^{\circ} \mathrm{C}$ in the dark for $7 \mathrm{~min}$. Absorbance was measured at $734 \mathrm{~nm}$ using a microplate reader, and the antioxidant activity was reported in $\mathrm{mmol} \mathrm{TE} / \mathrm{g} \mathrm{DW}$.

\section{Determination of reducing power}

The quantities of methanol-acetone and aqueous extracts used were $15,30,50,125,250$ and $500 \mu \mathrm{l}$, and $500 \mu \mathrm{l}$ of chloroform and acetogenin fractions. They were mixed with phosphate buffer $(2.5 \mathrm{~mL}$, $0.2 \mathrm{M}, \mathrm{pH} 6.6)$ and potassium ferric cyanide (K3Fe (CN), $2.5 \mathrm{ml}, 1 \%)$. The mixture was incubated at $50^{\circ} \mathrm{C}$ for 20 minutes. Trichloroacetic acid $(2.5 \mathrm{~mL})$ at $10 \%$ was added to stop the reaction, and the mixture was then centrifuged at $1000 \mathrm{~g}$ for $10 \mathrm{~min}$. A $2.5 \mathrm{ml}$ of the upper layer of the solution was mixed with $2.5 \mathrm{~mL}$ distilled water and $0.5 \mathrm{~mL}$ of ferric chloride $(0.1 \%)$, and the absorbance was measured at $700 \mathrm{~nm}$. The increased absorbance of the reaction mixture indicated an increase of the reducing power. An ascorbic acid (AA) calibration curve was used, and determination of reducing power was expressed as micromole AA equivalent ( $\mu \mathrm{M}$ AA equivalent) [20].

\section{Scavenging of nitric oxide (NO) radical assay}

Sodium nitroprusside $(5 \mathrm{mM})$ in phosphate buffered saline ( $\mathrm{pH} 7.4)$ was mixed with samples $(15,30,50,125,250$ and $500 \mu \mathrm{l})$ of methanolacetone, aqueous and antioxidant control, or $500 \mu \mathrm{l}$ of chloroform and acetogenin fraction, and then incubated at $25^{\circ} \mathrm{C}$ for $150 \mathrm{~min}$. The samples were then allowed to react with Greiss reagent, and the absorbance of the formed chromophore was measured at $546 \mathrm{~nm}$. Ascorbic acid standard was used as a positive control. The scavenging percentage of NO radical assay was calculated using the formula: \% inhibition of NO radical activity $=$ (absorbance of positive controlabsorbance of test sample)/ (absorbance of positive control) x 100 [21]. 


\section{Determination of the total antioxidant activity}

The quantities of methanol-acetone and aqueous extracts used were $15,30,50,125,250,500 \mu \mathrm{l}$, and $500 \mu \mathrm{l}$ of chloroform and acetogenin fraction. They were combined with reagent solution $(0.6 \mathrm{M}$ sulfuric acid, $28 \mathrm{mM}$ sodium phosphate and $4 \mathrm{mM}$ ammonium molybdate) [22]. The tubes were capped and incubated in a water bath at $95^{\circ} \mathrm{C}$ for $90 \mathrm{~min}$. The samples were then cooled at room temperature, and the absorbance was measured at $695 \mathrm{~nm}$ against a blank (methanol) using a spectrophotometer (Jenway 6705, Beacon Road, UK). A vitamin E (a-tocopherol) calibration curve was used and the total antioxidant activity was expressed as microgram of vitamin $\mathrm{E}$ equivalent ( $\mu \mathrm{g} \alpha$ tocopherol equivalent).

\section{Statistical analysis}

All analyses were performed in triplicates. The experimental data were analyzed with ANOVA (software STATISTICA, v.8 StatSoft). Means comparison was made by the least significant difference (LSD, a $=0.05)$.

\section{Results and discussion}

\section{Total soluble phenolic compounds (TSP)}

Methanol-acetone extract had the highest content of TPS with values of $3.20 \mathrm{~g} / 100 \mathrm{~g} \mathrm{DW}(50 \mu \mathrm{l})$, while the aqueous extract had 1.47 $\mathrm{g} / 100 \mathrm{~g}$ DW (Figure 2). Lower values of TSP were detected in chloroform extract and acetogenin fraction, with 0.72 and $0.032 \mathrm{~g} / 100 \mathrm{~g}$ DW (Table 1).

\begin{tabular}{|l|l|l|}
\hline Parameter & Chloroform Extract & Acetogenin fraction \\
\hline $\begin{array}{l}\text { Total soluble polyphenols } \\
(\mathrm{mg} / \mathrm{g} \mathrm{DW})\end{array}$ & $0.72 \pm 0.02$ & $0.032 \pm 0.001$ \\
\hline ABTS assay (mmol TE/g DW) & $22.19 \pm 0.15$ & $4.91 \pm 0.23$ \\
\hline DPPH assay (mmol TE/g DW) & $1.02 \pm 0.14$ & $0.58 \pm 0.07$ \\
\hline $\begin{array}{l}\text { Reducing power ( } \mu \mathrm{M} \quad \mathrm{AA} \\
\text { equivalent) }\end{array}$ & $23.85 \pm 0.07$ & $21.77 \pm 0.39$ \\
\hline $\begin{array}{l}\text { Total antioxidant activity }(\mu \mathrm{g} \alpha- \\
\text { tocopherol equivalent) }\end{array}$ & $33.76 \pm 2.91$ & $4.85 \pm 2.10$ \\
\hline
\end{tabular}

Table 1: Total soluble polyphenols and antioxidant activity of chloroform extract and acetogenin fraction obtained from Annona muricata fruit pulp.

Polyphenols have a large number of unsubstituted hydroxyl groups or sugars considered as polar molecules, so they are soluble in polar solvents such as methanol, ethanol, acetone or water. The effect of water, methanol, ethanol and acetone in the extraction of polyphenols and antioxidants was investigated in 37 fresh plant species and was found that distilled water was the most inefficient solvent for extracting polyphenols [23].

This might be due to the oxidation of phenols by the action of polyphenol oxidase, which is active in the aqueous medium, while the extracts of methanol, ethanol and acetone inactivate this enzyme, and therefore soluble polyphenol extraction is better with methanolacetone [23]. Soursop pulp contains significant amounts of soluble polyphenols $[2,12]$, and some phenolic compounds include cinnamic acid derivatives, coumaric acid derivatives, and caffeic acid derivatives [3].

The TSP level in the methanol-acetone extract found in this study was almost two times higher than the reported values in soursop pulp (0.104 to $1.86 \mathrm{~g}$ GAE /100 g DW) [2,12]. This indicates that solvents and extraction methods influence the polyphenolic content. Soursop fruit pulp had a TSP quantity equal or higher than what was reported in other fruits such as 'Wl' peach (0.09 g GAE/100 g DW), 'Sel-42' papaya $(0.17 \mathrm{~g} / 100 \mathrm{~b} \mathrm{DW})$, and 'Ataulfo' mango (0.43 g/100g DW) $[24,25,26]$. On the other hand, it has been desmonstrated that there are compounds, such as flavonoids, which are soluble in organic solvents such as chloroform, dichloromethane, diethyl ether or ethyl acetate [23], and for this reason TSP were identified in chloroform extract and acetogenin fraction when $50 \mu$ lof extract was used.

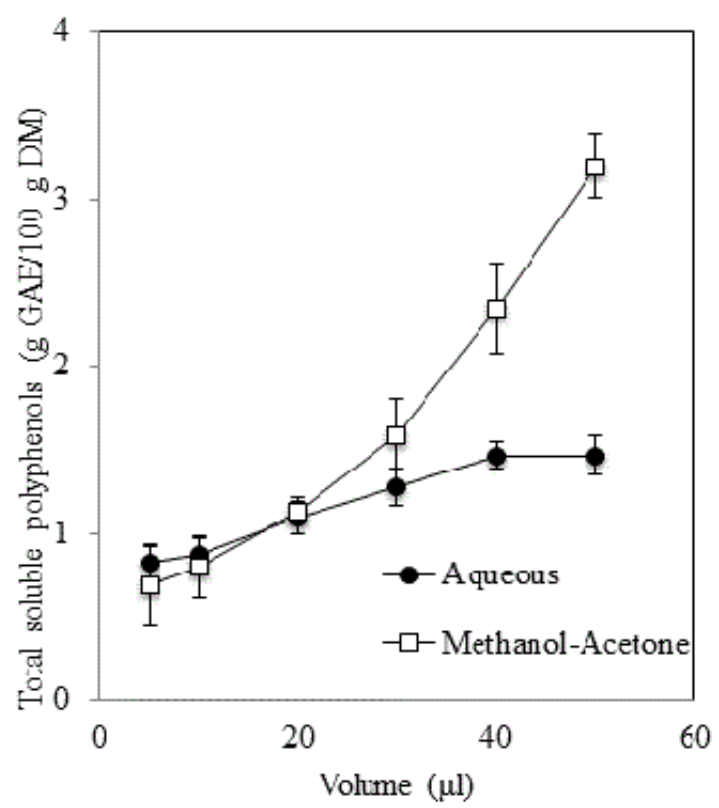

Figure 2: Total soluble phenolic content from aqueous and methanol-acetone extracts.

\section{ABTS and DPPH radical scavenging activities}

The values of antioxidant activity determined by ABTS and DPPH radical scavenging assays are shown in Figures $3 a$ and $3 b$, respectively. Antioxidant capacity with ABTS assay was slightly lower in all used volumes of methanol-acetone extracts (52.96-53.91 mmol TE/g DW), in comparison with the control antioxidant (57.67-58.89 mmol TE/g DW). Also, when $30 \mu \mathrm{l}$ of aqueous extract were used, an antioxidant activity of $57.40 \mathrm{mmol} \mathrm{TE} / \mathrm{g} \mathrm{DW}$ was measured. Using the DPPH assay, the control antioxidant had values of 56.82-58.61 mmol TE/g DW, while methanol-acetone extract presented an antioxidant activity of $49.47 \mathrm{mmol} \mathrm{TE} / \mathrm{g}$ DW when $50 \mu \mathrm{l}$ was used, followed by aqueous extract (31.49 $\mathrm{mmol} \mathrm{TE} / \mathrm{g} \mathrm{DW})$.

It has been demonstrated that polyphenols may act via multiple mechanisms of radical-scavenging activity such as metal scavengers, transferring electrons or donating hydrogen ions; most notably the high molecular weight phenolics (tannins) have more ability to quench 
Page 4 of 7

free radicals such as ABTS $\bullet+$ and DPPH $\bullet+[27,28]$. On the other hand, the differences in the antioxidant capacity between the DPPH and ABTS assays could be attributed to the different concentrations of polyphenols, and also depend to a higher extent on their chemical composition [29].

The position of hydroxyl groups seems to be more important for antioxidant capacity (DPPH, ABTS) of polyphenols. For example, hydroxyl groups in the ortho position of $B$ ring can greatly enhance the antioxidant capacity (using the ABTS assay), such as in catechins or proanthocyanidins (oligomers and polymers of catechins) [30].
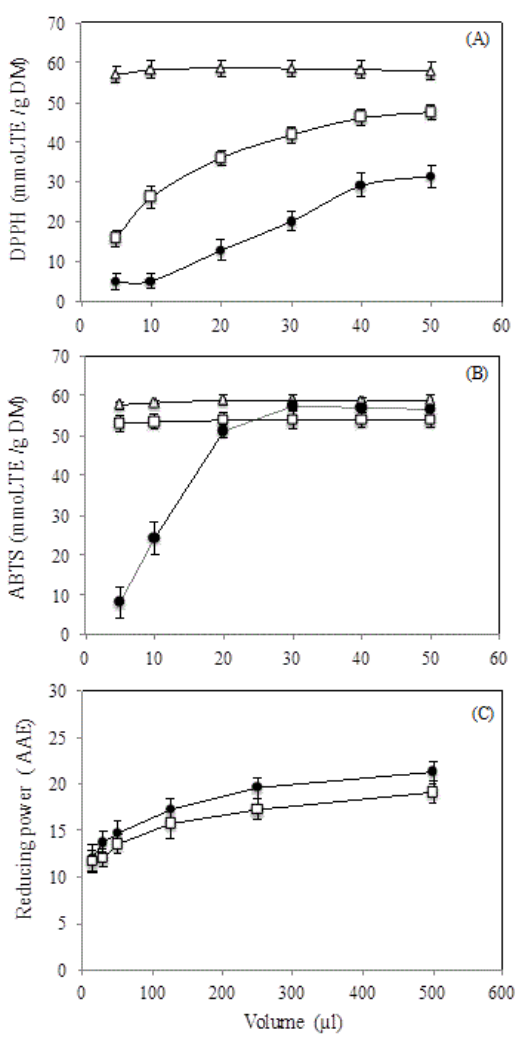

Figure 3: Antioxidant capacity determined by 1,1'-Diphenyl-2picrylhydrazyl (DPPH) assay (A), 2,2-Azinobis-3ethylbenzotiazoline-6-sulfonic acid (ABTS) radical scavenging assay (B) and reducing power (C) on control antioxidant (ascorbic acid), aqueous and methanol-acetone extracts.

The results from the DPPH assays in this work were higher than what reported in soursop ethanol-water extract (6.45 $\mathrm{mg}$ TE/g DW) [31]. In addition, lower values of antioxidant activity (4.4 and 6.09 $\mu \mathrm{mol} \mathrm{TE} / \mathrm{g} \mathrm{DW})$ were reported in soursop pulp harvested in Brazil $[32,33]$.

Although it is difficult to compare the antioxidant activity of fruits due to the differences in extraction conditions, but it is possible that the highest values of antioxidant activity determined by DPPH or ABTS assays in this work are related with the high polyphenol content found in the methanol-acetone extract.

There were significant correlations between TSP and antioxidant activities using ABTS and DPPH assays (Table 2).

\begin{tabular}{|l|l|l|l|}
\hline Correlation & Extract & R2 & Extintion coeficient \\
\hline- & Aqueous & 0.808 & 67.085 \\
\hline TSP-ABTS* & $\begin{array}{l}\text { Methanol- } \\
\text { acetone }\end{array}$ & 0.759 & 0.251 \\
\hline- & Aqueous & 0.982 & 40.529 \\
\hline TSP-DPPH** & $\begin{array}{l}\text { Methanol- } \\
\text { acetone }\end{array}$ & 0.747 & 11.250 \\
\hline- & Aqueous & 0.901 & 26.315 \\
\hline $\begin{array}{l}\text { TSP-Total antioxidant } \\
\text { capacity }\end{array}$ & $\begin{array}{l}\text { Methanol- } \\
\text { acetone }\end{array}$ & 0.921 & 17.175 \\
\hline TSP-Reducing power & Aqueous & 0.876 & 11.066 \\
\hline- & $\begin{array}{l}\text { Methanol- } \\
\text { acetone }\end{array}$ & 0.986 & 3.905 \\
\hline- & Aqueous & 0.891 & 45.778 \\
\hline TSP-Nitric oxide & $\begin{array}{l}\text { Methanol- } \\
\text { acetone }\end{array}$ & 0.690 & 7.737 \\
\hline
\end{tabular}

Table 2: Regression coefficient (R2) and extinction coefficient correlations between total soluble polyphenols (TSP) values and antioxidant capacity.

A strong positive correlation was found between antioxidant activities determined by both scavenging assays (DPPH and ABTS) and total phenolics and flavonoids contents in 50 of the most popular antioxidant-rich fruits such as mango, pineapple and guava, among others [27].

Chloroform extract or acetogenin fraction (Table 1) showed an antioxidant activity by ABTS assay of 22.19 and $4.91 \mathrm{mmol} \mathrm{TE} / \mathrm{g} \mathrm{DW}$, respectively; or $1.02 \mathrm{mmol} \mathrm{TE} / \mathrm{g} \mathrm{DW}$ and $0.58 \mathrm{mmol} \mathrm{TE} / \mathrm{g} \mathrm{DW}$ with the $\mathrm{DPPH}$ assay. The antioxidant activity in organic samples, as chloroform extract and acetogenin fraction, is probably due to the presence of flavonoids with low polarity, which can be extracted with chloroform, dichloromethane, diethyl ether or ethyl acetate [23]. Significant antioxidant activity was reported using DPPH and ABTS assays in Commelina nudiflora when organic solvents were used as extracts [33]. In another study, it was found that ethanol extract of Annona cornifolia, as well as the chloroform fraction and isolated acetogenins, showed high antioxidant activity by DPPH assay, and this was associated with the acetogenin concentration and phenolic compounds in the extracts [10]. The DPPH antiradical activity of the acetogenins may be related to the $\alpha, \beta$-unsaturated lactone ring moiety, similar to the in vitro mechanism of action of ascorbic acid, in which allylic hydrogens are involved. Acetogenins should act in the same way, since they also possess allylic hydrogens, as well as the stabilization via electron delocalization in the $\alpha, \beta$-unsaturated lactone ring moiety. A piece of evidence to support these observations is ascorbate, which naturally occurs in plants, and contains hydroxyl groups attached to a saturated lactone ring. This compound exhibited very little scavenging activity towards DPPH free radicals [10], possibly due to the low antioxidant capacity of chloroform extract and acetogenin fraction. 


\section{Reducing power activity}

Reducing power activity was used to measure the reducing capacity of extracts (Figure $4 c$ ). There were no significant differences ( $p>0.05$ ) in reducing power activity between aqueous and methanol-acetone extracts, and the values oscillated between 19.06 and $21.19 \mu \mathrm{M}$ AA equivalent when $500 \mu \mathrm{l}$ was used. Also, the chloroform extract and acetogenin fraction (Table 1 ) had a reducing power activity of 23.85 and $21.77 \mu \mathrm{M}$ AA equivalent, respectively. The reducing power activity found in all extracts is probably a result of the combined effect of each of the compounds in the extracts [34]. In addition, polyphenols, including flavonoids that are soluble in less polar solvents, may be able to chelate metal ions such as iron and copper because of the large number of hydroxil groups $(\mathrm{OH})$ of their chemical structure, which are responsible for conferring the chelating ability $[34,35]$. The correlation between TSP and reducing power was $\mathrm{R} 2=0.87-0.98$ (Table 2). Therefore, it is possible that the presence of polyphenols in all extracts and acetogenins fraction can explain the ferric reducing power abilities. In a similar study using methanolic and aqueous extracts of Annona squamosa fruit pulp, $59 \mu \mathrm{g}$ and $46 \mu \mathrm{g}$ AAE of reducing power activity were reported, respectively [35]. This indicates that reducing power activity can vary in different Annona species.

\section{Scavening of nitric oxide (NO) radical activity}

The methanol-acetone and aqueous extracts exhibited a good NO scavenging activity. With $50 \mu \mathrm{l}$ of methanol-acetone and aqueous extracts, the percentage of inhibition was 64.5 and $59.2 \%$, respectively (Figure 3b). This increased with $500 \mu \mathrm{l}$ of extracts to 81 and $70 \%$ due to a higher volume, higher concentration of phenolic compounds that achieved a significant difference, and thus NO scavenging activity was higher in methanol-acetone extract than in control antioxidant $(67.4 \%)$ and aqueous extract. The NO radical is generated in the human body and its function was elucidated in a variety of pharmacological conditions including inflammation, carcinogenesis, atherosclerosis, and excess of $\mathrm{NO}$ production or the peroxynitrite radical (ONOO-) produced from the reaction with $\mathrm{O}_{2^{-}}$, causing oxidative damage to membrane lipid peroxidation, DNA fragmentation and lipoprotein oxidation [36]. Muthu \& Durairaj [37] found that percentage inhibition of NO radical was $63.2 \%$ at $100 \mu \mathrm{g} / \mathrm{ml}$ with an ethanolic extract (leves of Annona muricata). The antioxidant activity of soluble phenols could have a potential to inhibit $\mathrm{NO}$ or nitrogen radical species, such as $\mathrm{NO}_{2}$ or the intermediate radicals, $\mathrm{N}_{2} \mathrm{O}_{3}$ and $\mathrm{N}_{2} \mathrm{O}_{4}$, during $\mathrm{NO}$ oxidation as previous studies have reported that a phenolic groups would be an important factor for NO suppression [38,39]. The NO scavenging action for total soluble polyphenols may also be due to $\mathrm{OH}$-substituted functional group in the structure, NO level indirectly from nitrite, nitrate is reduced to nitrite enzymatically via nitrate reductase so that the total amount of nitrite can be measured [38,39]. The best NO scavenging activity was obtained with methanolic extract (79.3\%) compared with aqueous extract (57.8\%) of $A$. squamosa fruit pulp [35]. In A. muricata, methanol-acetone extract was more effective against this radical, and this is principally attributed to soluble polyphenols. No NO scavenging activity was detected in chloroform extract and acetogenin fraction, which is possibly due to the low amount of phenols found in these extracts.

\section{Total antioxidant activity}

Total antioxidant activity of methanol-acetone and aqueous extracts was 222 and $86.5 \mathrm{mg}$ a-tocopherol equivalent, with $500 \mu \mathrm{l}$ respectively
(Figure 4a). While chloroform extract and acetogenin fraction had values of 33.8 and $4.9 \mathrm{mg}$ a-tocopherol equivalent, respectively. The results coincided with those of TSP, DPPH and ABTS antioxidant activity and correlations between the three are shown in Table 2 . The total antioxidant activity assay indicates that most activity in soursop pulp is due to polyphenol content, and minor proportions to intervening acetogenins. It has been demonstrated that most polar solvents, such as methanol and acetone, extracted higher content of phenolic compounds and conferred the highest total antioxidant capacity of $A$. squamosa [34,39].
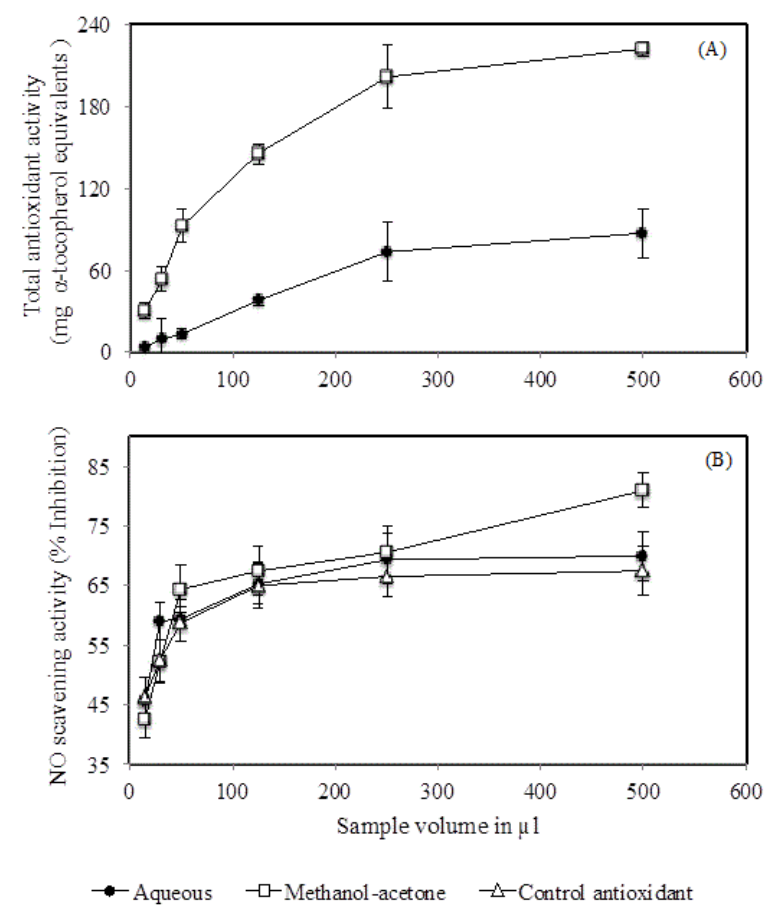

Figure 4: Total antioxidant capacity (A) and scavenging nitric oxide (NO) (B) of aqueous and methanol-acetone extracts.

\section{Conclusion}

Extraction of total soluble polyphenols from soursop fruit pulp with methanol-acetone had a potent in vitro antioxidant activity when measured with DPPH, ABTS, nitric oxide and total antioxidant activity assays. Aqueous extract presented good antioxidant capacity by ABTS and nitric oxide assays. Chloroform extract and acetogenin fraction also had antioxidant capacity but it was high only when measured by the reducing power assay. The results indicate that soursop fruit pulp has high antioxidant properties making this fruit potentially functional.

\section{Acknowledgment}

The authors gratefully acknowledge the financial support of The Coca-Cola Company and CONACYT for a student grant (371429). 


\section{Declaration of Interest Statement}

The authors declare that they have no conflict of interest.

\section{References}

1. Pinto ADQ, Cordeiro MCR, De Andrade SRM, Ferreira FR, Filgueiras HA, et al. (2005) Annona species. In: Annona 1. Tropical fruit trees. Williams JT, Smith RW, Hughes A, Haq N, Clement CR, International Centre for Underutilised Crops, Southampton, UK.

2. Moreno-Hernández CL, Sáyago-Ayerdi SG, García-Galindo HS, MataMontes De Oca M, Montalvo-González E (2014) Effect of the application of 1-methylcyclopropene and wax emulsions on proximate analysis and some antioxidants of soursop (Annona muricata L.). ScientificWorldJournal 2014: 896853.

3. Jiménez VM, Gruschwitz M, Schweiggert RM, Carle R, Esquivel, P (2014) Identification of phenolic compounds in soursop (Annona muricata) pulp by high-performance liquid chromatography with diode array and electrospray ionization mass spectrometric detection. Food Res Int 65 42-46.

4. Andrade JMM, Fasolo D (2014) Polyphenol antioxidants from natural sources and contribution to health promotion, Academic Press, San Diego, USA.

5. Coria-Téllez AV, Montalvo-Gónzalez E, Yahia EM, Obledo-Vázquez EN (2016) Annona muricata: A comprehensive review on its traditional medicinal uses, phytochemicals, pharmacological activities, mechanisms of action and toxicity. Arabian Journal of Chemistry.

6. Potts LF, Luzzio FA, Smith SC, Hetman M, Champy P, et al. (2012) Annonacin in Asimina triloba fruit: implication for neurotoxicity. Neurotoxicology 33: 53-58.

7. Venâncio VP, Ferreira EB, Brigagão MRPL, Paula FBDA, Barbisan LF, et al. (2013) Annona crassiflora Mart. fruit pulp effects on biochemica parameters and rat colon carcinogenesis. Ciên Agrotec 37: 343-349.

8. Hamizah S, Roslida AH, Fezah O, Tan KL, Tor YS, et al. (2012) Chemopreventive potential of Annona muricata L leaves on chemicallyinduced skin papillomagenesis in mice. Asian Pac J Cancer Prev 13 2533-2539.

9. Paulinus O, Kinsley A, Ikechi E (2013) Protective effect of ethanolic leaf extract of Annona muricata Linn on some early events in cycas-induced colorectal carcinogenesis in rats. J Pharm Scien Innov 2: 14-21.

10. Lima LAS, Pimenta LP, Boaventura MAD (2010) Acetogenins from Annona cornifolia and their antioxidant capacity. Food Chem 122: 1129-1138.

11. Prieto MA, Curran TP, Gowen A, Vázquez JA (2015) An efficient methodology for quantification of synergy and antagonism in single electron transfer antioxidant assays. Food Res Int 67: 284-298.

12. Isabelle M, Lee BL, Lim MT, Koh WP, Huang D, et al. (2010) Antioxidant activity and profiles of common fruits in Singapore. Food Chem 123: 77-84.

13. Melot A, Fall D, Gleye C, Champy P (2009) Apolar Annonaceous acetogenins from the fruit pulp of Annona muricata. Molecules 14: 4387-4395.

14. Pérez-Jiménez J, Arranz S, Tabernero M, Díaz-Rubio ME, Serrano J, et al (2008) Updated methodology to determine antioxidant capacity in plant foods, oils and beverages: Extraction, measurement and expression of results. Food Res Int 41: 274-285.

15. Gu Z, Zhao G, Oberlies NH, Zeng L, McLaughlin JL (1996) In Recent Advances in Phytochemestry. Plenum Press 29: 249-310.

16. Montreau F (1972) Sur le sodage des composés phénoliques totax dans les vins par la méthode Folin-Ciocalteu. Connaiss Vigne 24: 397-404.

17. Alvarez-Parrilla E, De La Rosa LA, Legarreta P, Saenz L, Rodrigo-García J, et al. (2010) Daily consumption of apple, pear and orange juice differently affects plasma lipids and antioxidant capacity of smoking and non-smoking adults. Int J Food Sci and Nutr 61: 369-380.
18. Prior RL, Wu X, Schaich K (2005) Standardized methods for the determination of antioxidant capacity and phenolics in foods and dietary supplements. J Agric Food Chem 53: 4290-4302.

19. Re R, Pellegrini N, Proteggente A, Pannala A, Yang M, et al. (1996) Antioxidant activity applying an improved ABTS radical cation decolorization assay. Free Radical Biol Med 26: 1231-1237.

20. Yen GC, Chen HY (1995) Antioxidant activity of various tea extracts in relation to their antimutagenicity. J Agric Food Chem 43: 27-32.

21. Green LC, Wagner DA, Glogowski J, Skipper PL, Wishnok JS, et al. (1982) Analysis of nitrate, nitrite, and [15N]nitrate in biological fluids. Anal Biochem 126: 131-138.

22. Prieto P, Pineda M, Aguilar M (1999) Spectrophotometric quantitation of antioxidant capacity through the formation of a phosphomolybdenum complex: specific application to the determination of vitamin E. Anal Biochem 269: 337-341.

23. Sulaiman SF, Sajak AAB, Ooi KL, Seow EM (2011) Effect of solvents in extracting polyphenols and antioxidants of selected raw vegetables. J Food Comp Anal 24: 506-515.

24. Liu H, Cao J, Jiang W (2015) Evaluation and comparison of vitamin C, phenolic compounds, antioxidant properties and metal chelating activity of pulp and peel from selected peach cultivars. Food Sci Tech. 63: 1042-1048.

25. Kelebek H, Selli S, Gubbuk H, Gunes E (2015) Comparative evaluation of volatiles, phenolics, sugars, organic acids and antioxidant properties of Sel-42 and Tainung papaya varieties. Food Chem 173: 912-919.

26. Palafox-Carlos H, Yahia EM, González-Aguilar GA (2012) Identification and quantification of major phenolic compounds from mango (Mangifera indica, cv. Ataulfo) fruit by HPLC-DAD-MS/MS-ESI and their individual contribution to the antioxidant activity during ripening. Food Chem 135: 105-111.

27. Paz M, Gúllon P, Barroso MF, Carvalho AP, Domingues VF, et al. (2015) Brazilian fruit pulps as functional foods and additives: evaluation of bioactive compounds. Food Chem 172: 462-468.

28. Pérez-González A, Rebollar-Zepeda AM, León-Carmona JR, Galano A (2012) Reactivity indexes and OH bond dissociation energies of a large series of polyphenols: Implications for their free radical scavenging activity. J Mex Chem Soc 56:241-249.

29. Loizzo MR, Tundis R, Bonesi M, Menichini F, Mastellone V, et al. (2012) Radical scavenging, antioxidant and metal chelating activities of Annona cherimola Mill.(cherimoya) peel and pulp in relation to their total phenolic and total flavonoid contents. J Food Comp Anal 25: 179-184.

30. Bouayed J, Hoffmann L, Bohn T (2011) Antioxidative mechanisms of whole-apple antioxidants employing different varieties from Luxembourg. J Med Food 14: 1631-1637.

31. Beserra MM, Machado PH, Campos AM, Matias G, De Carvalho CE, et al. (2011) Bioactive compounds and antioxidant activity of fresh exotic fruits from northeastern Brazil. Food Res Int 44: 2155-2159.

32. Floegel A, Kim DO, Chung SJ, Koo SI, Chun OK (2011) Comparison of ABTS/DPPH assays to measure antioxidant capacity in popular antioxidant-rich US foods. J Food Comp Anal 24: 1043-1048.

33. Gavamukulya Y, Abou-Elella F, Wamunyokoli F, AEl-Shemy H (2014) Phytochemical screening, anti-oxidant activity and in vitro anticancer potential of ethanolic and water leaves extracts of Annona muricata (Graviola). As Pac J trop med 7: S355-S363.

34. Sánchez-Vioque R, Polissiou M, Astraka K, de los Mozos-Pascual M, Tarantilis P, et al. (2013) Polyphenol composition and antioxidant and metal chelating activities of the solid residues from the essential oil industry. Ind Crop Prod 49: 150-159.

35. Nandhakumar E, Indumathi P (2013) In vitro antioxidant activities of methanol and aqueous extract of Annona squamosa (L.) fruit pulp. J Acupunct Meridian Stud 6: 142-148.

36. Taira J, Tsuchida E, Katoh MC, Uehara M, Ogi T (2015) Antioxidant capacity of betacyanins as radical scavengers for peroxyl radical and nitric oxide. Food Chem 166: 531-536 
Citation: León-Fernández AL, Sáyago-Ayerdi SG, Velázquez-Estrad RM, Zepeda-Vallejo LG, Yahia E, et al. (2017) In Vitro Antioxidant Capacity of Crude Extracts and Acetogenin Fraction of Soursop Fruit Pulp. Pharm Anal Acta 8: 550. doi:10.4172/2153-2435.1000550

Page 7 of 7

37. Muthu S, Durairaj B (2015) Evaluation of antioxidant and free radical scavenging activity of Annona muricata. Euro J Exp Biol 5: 39-45.

38. Ebrahimzadeh MA, Nabavi SF, Nabavi SM, Pourmorad F (2013) Nitric oxide radical scavenging potential of some Elburz medicinal plants. Afri J Biotech 9: 5212-5217.
39. Haenen GR, Paquay JB, Korthouwer RE, Bast A (1997) Peroxynitrite scavenging by flavonoids. Biochem Biophys Res Commun 236: 591-593. 